DOI: 10.22616/REEP.2021.14.051

\title{
Students' and Teachers' Opinion on the Possibilities of Improving Students' Research Skills in Biology Lessons
}

\author{
(D)Juris Porozovs ${ }^{1}$ Dr. biol.; Soneta Grosberga-Merca ${ }^{2}$ Bc. paed. \\ University of Latvia, Latvia ${ }^{1}$; P. Stradins Medical College of the University of Latvia, Latvia ${ }^{2}$ \\ juris.porozovs@lu.lv; soneta20@inbox.lv²
}

\begin{abstract}
Acquisition of students' research skills in the learning process is one of the main goals in the educational process. The aim of the study was to clear out the opinion of students and teachers on the possibilities of improving students' research skills in biology lessons. The survey of the $10^{\text {th }}, 11^{\text {th }}$ and $12^{\text {th }}$-grade students about their opinion on the importance of research skills, the level of their research skills and possibilities of improving students' research skills in biology lessons were carried out in three secondary schools of Latvia. Altogether 142 students were surveyed. Three biology teachers were interviewed as well. The results of the research showed that most of the surveyed students appreciate the benefits of acquiring research skills. The majority of the surveyed students rate their level of research skills as average. Most of the students usually do not have problems with research activities. Students consider that the most difficult of the stages is nomination and justification of the hypothesis. The majority of surveyed students consider that most of the methods used in lessons have a middle or big influence on the development of research skills. Students consider that laboratory work has the greatest impact on the development of research skills. Students evaluate the teacher's activity in the learning process and consider that different activities used in Biology lessons promote the development of research skills. The surveyed biology teachers rate the students' research skills as good. Teachers are convinced that one of the most important preconditions for the development of research skills is the formation of interest in the relevant topic. Successful cooperation between teachers and students plays a crucial role in the development of students' scientific skills.
\end{abstract}

Keywords: research skills, secondary school students, teachers, biology lessons, teaching methods.

\section{Introduction}

There is a lot of discussion in education about the type of skills that young people will need to find a good job and thrive in the 21 st century. In order for students currently in education to be able to integrate into the society of the future and to be competitive, it is necessary to pay attention to what knowledge, skills and attitudes students will acquire upon graduation. Digital skills, the ability to lead and work in a team, communication skills, analytical and creative thinking are considered important skills for the specialist in the 21 st century (Van Damme, 2014). Special emphasis is also placed on such skills as the ability to see opportunities and identify problems, to be master in your own field, to come with new ideas and solutions and the ability to critically evaluate information. Many of these skills are closely connected to the acquisition of research skills. The task of the learning process becomes not only to acquire knowledge but the ability to apply it in different situations. The new competency approach in the science curriculum of Latvia requires students to acquire and use research skills to solve scientific and interdisciplinary problems (Regulations Regarding..., 2019). The use of research methods in the process of acquiring biology subjects ensures the creative use of the theoretical knowledge acquired by the student and develops the ability to independently plan and perform experimental activities, as well as to use the acquired research skills in other subjects.

According to international policy and curriculum documents, the acquisition of research skills is an important objective of secondary education. Scientific reasoning skills are not just for researchers but they are also increasingly relevant for making informed decisions in our everyday lives (Engelmann, Neuhaus, Fischer, 2016). However, learning to conduct qualitative research is a complex endeavour. Secondary school and college students should and they can conduct research to strengthen different skills including critical thinking. Acquisition of students' research skills promotes critical thinking but critical thinking is one of the major goals to achieve the educational goals (Mantaniari et al., 2020). Some of these recommendations for developing critical thinking are to include increasing the diversity of research types and choosing more precise data analysis techniques (Susetyarini, Fauzi, 2020). 
Research also has great potential to increase students' engagement if they choose research topics that resonate with their curiosity and interests (Scherff, Rush, 2019).

Research is based on the use of previously accumulated knowledge, optimal methodology and technical equipment, which results in the acquisition of new knowledge, facts and ideas, which is the main goal of the research process (Kalnina, 2012). Information literacy - obtaining, evaluating and using information - is a key element of scientific literacy. Information literacy depends on general information management skills as well as on domain-specific knowledge. Studies indicate that most students are able to identify information but show little concern for the reliability and validity of the information they locate (Schiffl, 2020). It is necessary to help the student to acquire the ability to work with various information and distinguish real information from false information (Anspoka, Kazaka, 2019). One of the tasks of pedagogues is to promote students' information literacy. Information literacy includes the search of information, identification of research questions, search for answers and appropriate use of information. Findings indicate that information literacy training could result in substantial improvements in basic literacy skills and that leads to the improvement of the quality of science fair projects in which students are engaged (McPherson, Dubé, 2016). An effective learning process necessitates the development of strategies that promote the effective use of information and communication technologies (ICT) for both students and teachers as well (Vronska, 2016). ICT gives positive impact on the different stages of the study process. The use of ICT helps students better involve in the study process, giving them possibilities for better acquiring new information and better communication during the study process (Porozovs, Dudkina, Valdemiers, 2019).

One of the methods for developing students' research skills is to improve their decision-making skills. The development of students' research skills is closely linked with inquiry-based learning, which in turn can improve the acquisition of students' metacognitive skills (Nunaki et al., 2019). Studies show that the involvement of students in solving socio-scientific problems by making informative and systematic decisions improve their decision-making skills (Nurtamara et al., 2020). Students should know not only how to perform experiments, but also the reasons for performing them. Having the concept of conducting research by integrating various techniques is especially important (Zhang, 2008). Research shows that students' scientific thinking and acquisition of research skills could be facilitated by organizing a science fair and collaborating with scientists (Grinnell et al., 2018). Students who receive scientific support find it easier to get research ideas, they can have more access to articles in books and journals that stimulate interest in science. Students' interest in science could be promoted by the transition from short-term to long-term science experiments (Chirikure, 2020). Long-term science experiments could be developed as group work. This would encourage student collaboration and reflection among students. Students would have no time constraints; they could go in work deeper and repeat the research if necessary. Cooperation of schools with higher education institutions in scientific work can promote the development of students' scientific skills and the formation of interests in science (Aizsila, 2013).

The success of the work of the teacher depends on the implementation of student-active approach, where the individual is considered a stakeholder, which itself determines the nature of the activity and communication (Zhanguzhinova, Magauova, Nauryzbaeva, 2016). An important role in achieving high learning outcomes and developing scientific skills has cooperation between the student and the teacher. The achievements of the learning process could be enhanced by the formative assessment and effective feedback between the teacher and the students. The teacher describes, explains or demonstrates the concepts or skills being taught or instructs students to carry out an investigation (Brookhart, 2010). During the formation of feedback between the student and the teacher, answers to questions about the learning process, completion of tasks, opportunities to lead oneself to the set goal and achievement of the planned results are given and received (Čakāne, 2018). It is important that the assessment of the work is useful for the student and that he/she will be able to use this information to improve the work.

The aim of the study was to clear out the opinion of students and teachers on the possibilities of improving students' research skills in biology lessons.

\section{Methodology}

The study was performed in three secondary schools (one Riga secondary school, one Riga district secondary school and one Kurzemes region secondary school). The survey of the $10^{\text {th }}, 11^{\text {th }}$ and $12^{\text {th }}$-grade 
secondary school students about their opinion on the importance of research skills, the level of their research skills and possibilities of improving students' research skills in biology lessons were carried out. Altogether 142 students were surveyed (40 students from Riga secondary school; 52 students from Riga district secondary school and 50 students from Kurzemes region secondary school). 50 tenth grade students, 51 eleventh grade students and 41 twelfth grade students were surveyed. All surveyed students studied biology as a separate subject. The Likert scale was used in some of the survey questions. 3 biology teachers - one from Riga secondary school, one from Riga district secondary school and one from Kurzemes region secondary school were interviewed as well. A semi-structured interview was used in the research. The aim of the interview was to find out the opinion of biology teachers on issues related to research skills and opportunities for their improvement in the teaching process. The research was carried out in 2020.

The research question was: do students understand the importance of research skills and what is their opinion about the possibilities of improving research skills in biology lessons?

\section{Results and Discussion}

The majority of surveyed students ( $73 \%$ of respondents) agree with the statement that research skills are one of the most important skills of the 21 st century (Figure 1). Only $6 \%$ of respondents do not agree with this statement but $21 \%$ of students do not have an opinion on this issue. The obtained results show that most of the surveyed students highly appreciate research skills. One of the reasons may be that many of the surveyed students plan to link their future profession to one of the fields dominated by exact subjects. Although research skills are developed in all subjects, they are more directly related to the exact subjects in which research work is required. Students' opinions can also be influenced by the media, which notes that it is necessary for people to be able to evaluate situations to distinguish truth from lies, thus increasing the importance of research skills not only in the life of the student but in the life of any person.

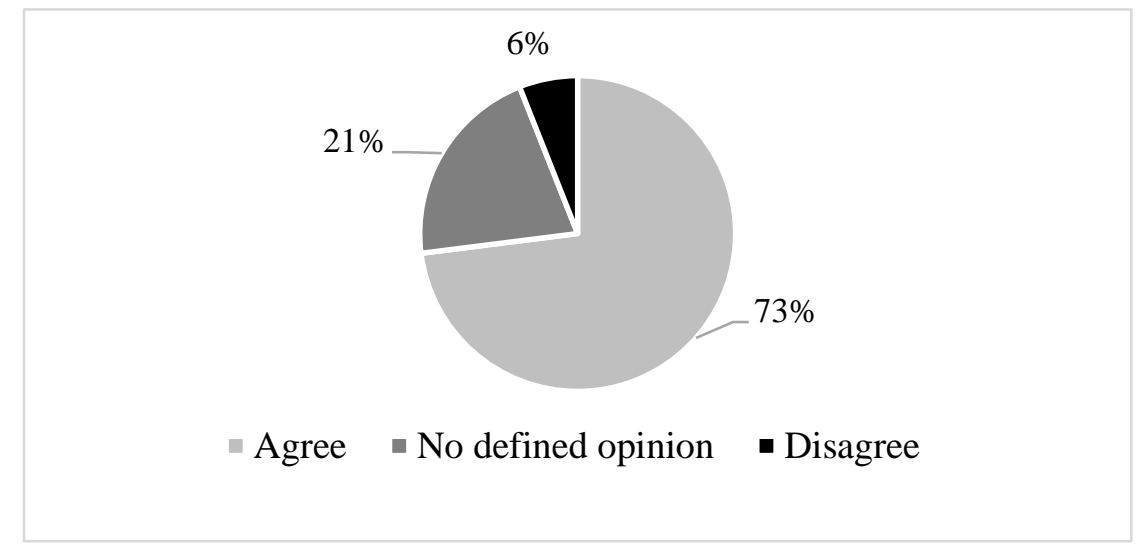

Figure 1. The opinion of secondary school students on the importance of research skills in the 21 st century (in \% of the number of students in the group).

The majority of surveyed students rather agree $(30 \%)$ or completely agree $(34 \%)$ with the statement that using methods for the development of research skills makes lessons more interesting (Figure 2). The majority of students also agree that using methods for the development of research skills helps to acquire knowledge and skills that will be useful in real-life situations (35\% of surveyed students completely agree and $39 \%$ of students rather agree), develops the ability to work independently, improves learning topic and encourages interest in the subject. 


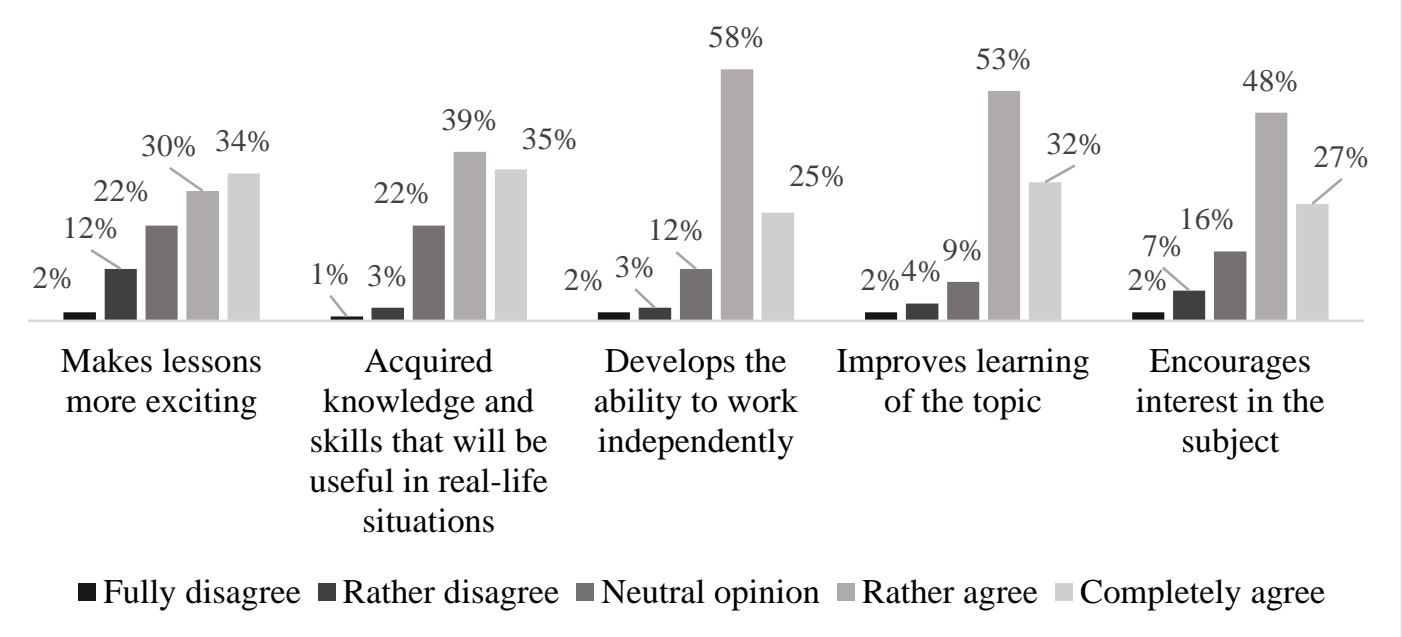

Figure 2. The opinion of secondary school students' on the benefits of using research methods in the lessons (in \% of the number of students in the group).

Most of the surveyed students rated their level of research skills as average (Figure 3). Eighteen percent of students consider their level of research skills to be high and only $2 \%$ rate it as very high but $10 \%$ of surveyed students think that their level of research skills is low. It is possible that students have underestimated the level of their research skills. Such results could be related to the incomplete knowledge of students about the formative assessment methods. Another reason for such results could be the student's lack of ability to evaluate his or her own work and achievements.

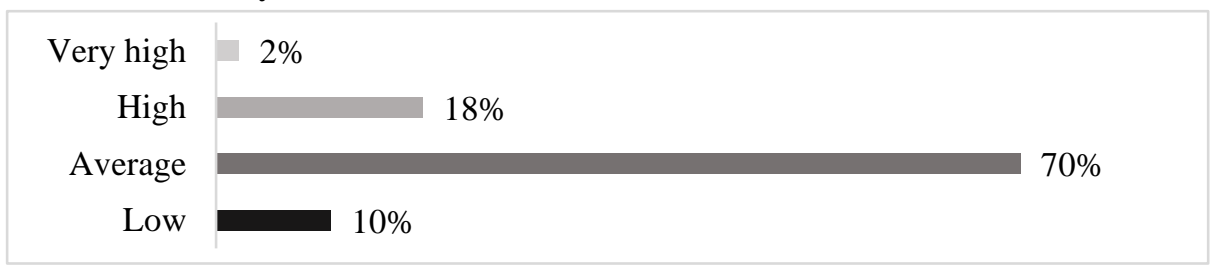

Figure 3. The opinion of secondary school students on their level of research skills (in $\%$ of the number of students in the group).

The largest number of students who have assessed their level of research skills as high is in Riga Secondary School (Figure 4). Eight percent of surveyed $10^{\text {th }}$-grade students, $8 \%$ of $12^{\text {th }}$-grade students and $17 \%$ of $11^{\text {th }}$-grade students have assessed their research skills as high. It is possible that this school pays more attention to the development of students' research skills, or that students are better taught how to assess their skills. Usually, students work out their scientific research work in 11th grade, which contributes to the development of research skills.

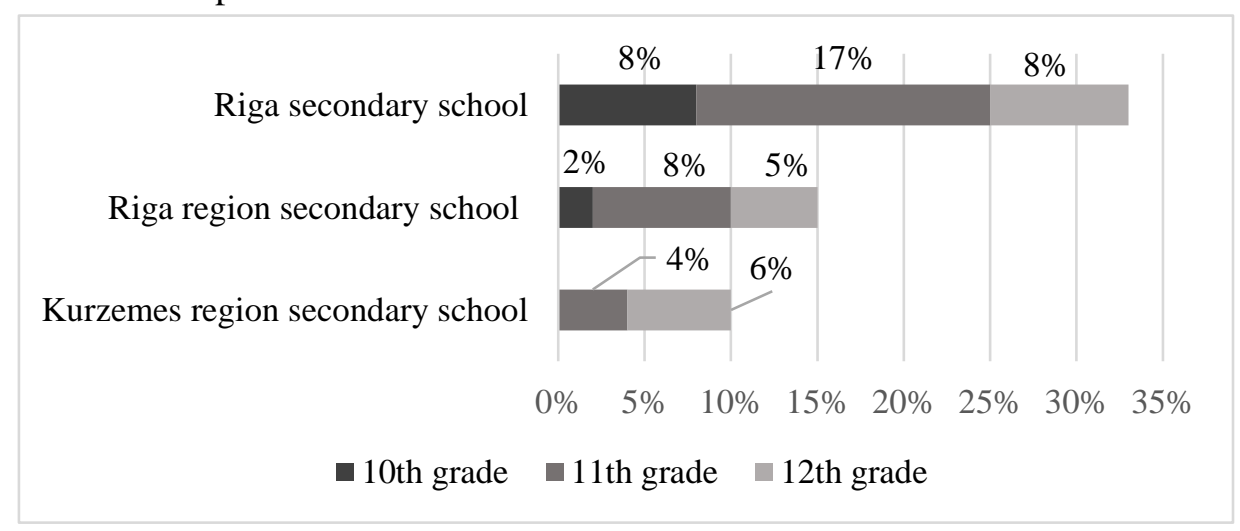

Figure 4. Distribution of secondary school students who rated their level of research skills as high by schools and class groups (in \% of the number of students in group). 
The answers provided by the respondents regarding the stages of the research activity show that students usually do not have any problems with research activities (Figure 5). According to the respondents, the most difficult of the stages is nomination and justification of the hypothesis, $5 \%$ of the respondents consider this stage to be difficult but $23 \%$ of the students consider this stage to be rather difficult. Students also consider acquisition and compilation of information to be a rather difficult stage (17\% of the students consider this stage to be rather difficult). Many students consider the making of conclusions to be the easiest stage ( $45 \%$ of students consider it a rather easy stage, but $13 \%$ consider it a very easy stage). The obtained survey data allow estimating of the research skills that students would need to develop the most. If students find it difficult nomination and justification of the hypothesis, then the skills to put forward and formulate a hypothesis need to be improved.

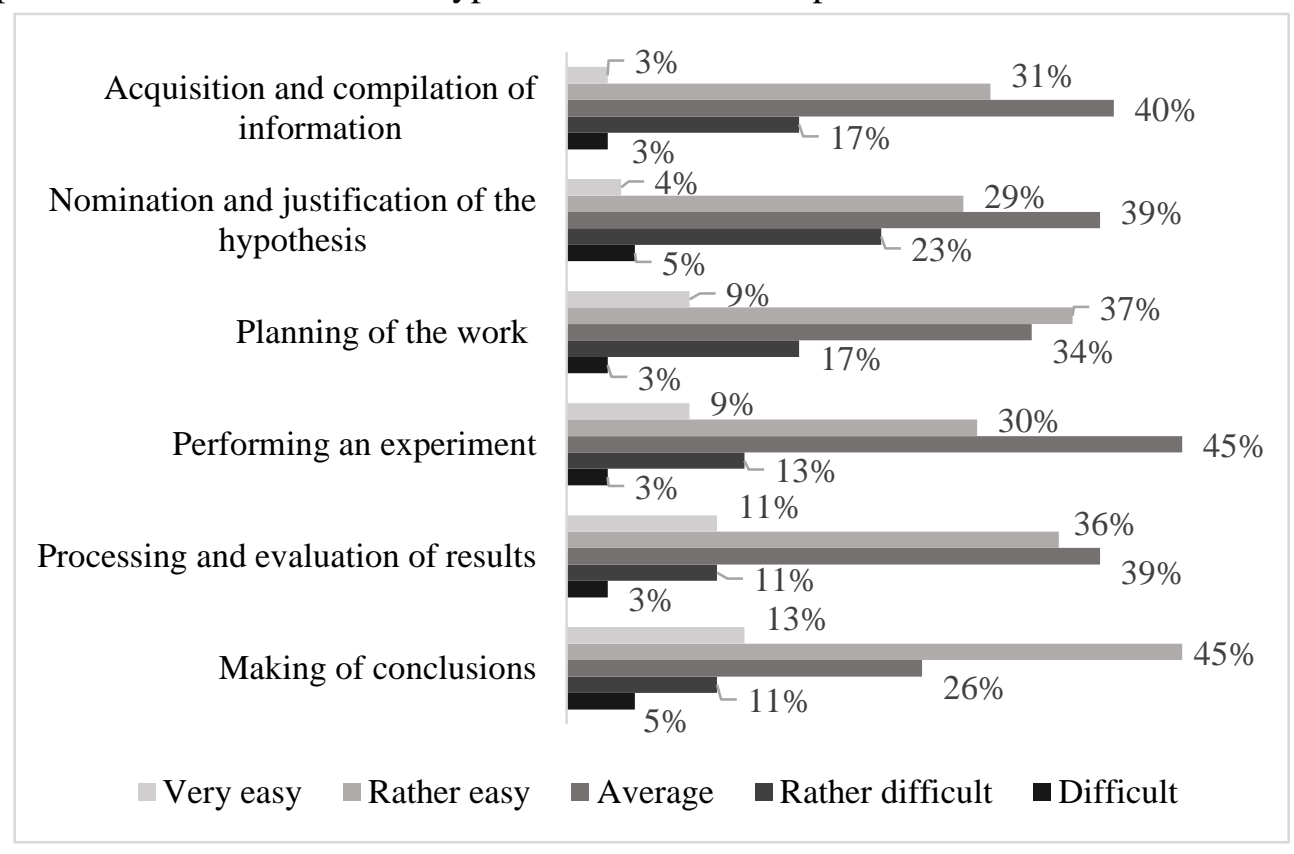

Figure 5. The opinion of secondary school students about the difficulties of the research stages (in \% of the number of students in the group).

The results of the survey show that the majority of students consider that most of the methods used in lessons have a middle or big influence on the development of research skills (Figure 6).

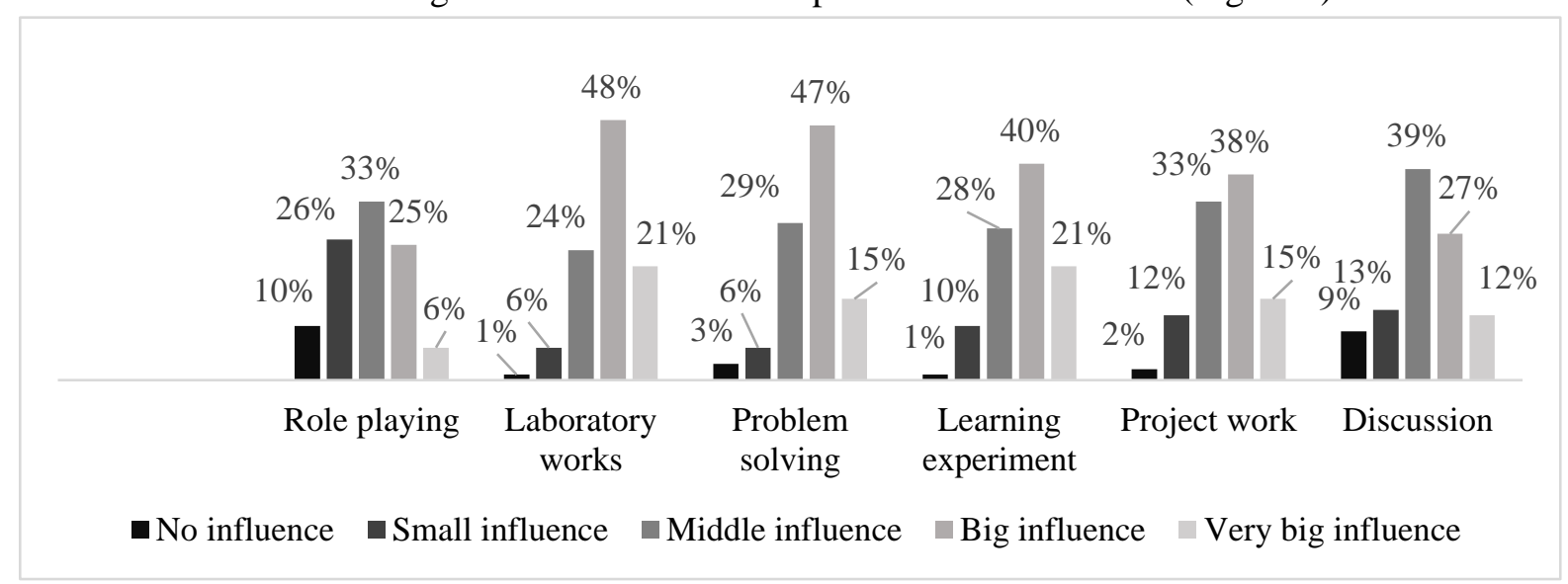

Figure 6. The opinion of secondary school students on the impact of teaching methods on the development of research skills (in \% of the number of students in the group).

Forty-eight percent of surveyed students consider that laboratory works have a big influence on the development of research skills and $47 \%$ of students consider that problem solving has a big influence on the development of research skills. Many students have underestimated the impact of role-playing on the development of research skills ( $26 \%$ of students consider that this method has a small influence on 
the development of research skills but $10 \%$ of surveyed students answered that role-playing has no influence on the development of research skills).

The surveyed secondary school students consider that different activities used in Biology lessons promote the development of research skills (Figure 7). The largest number of students (38\%) completely agree that the use of different teaching methods in Biology lessons promotes the development of research skills. Many students completely agree (32\% of students) or rather agree (40\% of students) the opinion that planning and management of lessons is an important factor for the development of students' research skills. Students consider that solving real-life examples and challenges in Biology lessons, asking questions that help students understand the research problem and other methods helps to develop students' research skills. The survey data confirm the students' opinion that the activity of teachers and the ability to organize lessons play an important role in the development of students' research skills.

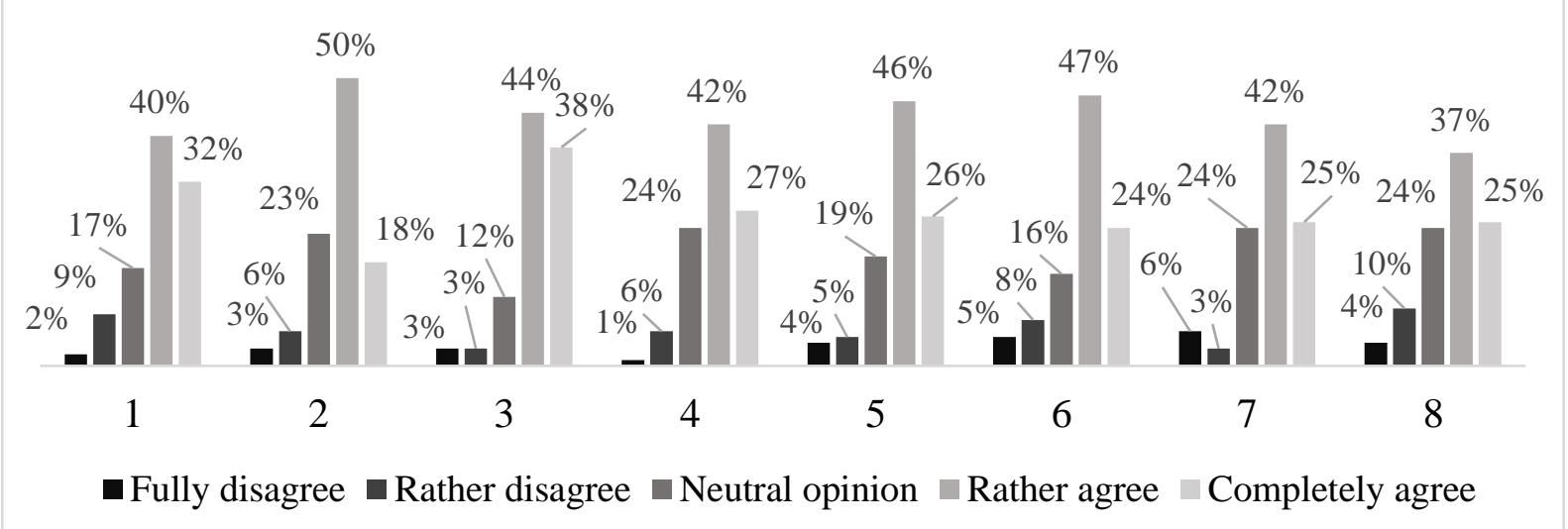

Figure 7. The opinion of secondary school students about the activities of teachers that promote the development of research skills in Biology lessons (in \% of the number of students in the group).

Explanation of symbols for Figure 7: 1 - Planning and management of lessons. 2 - Promotion of students' cooperation. 3 - Use of different teaching methods in lessons. 4 - Encouraging the application of what has been learned to explain new ideas. 5 - Solving real-life examples and challenges. 6 - Asking questions that help students develop an understanding of the research problem. 7 - Paying students' attention to the connections between the acquired knowledge and previous experience. 8 - Interviews with students to assess their understanding of the topic.

In interviews with biology teachers, teachers said that they use different methods to develop students' research skills such as learning experiments, laboratory works, work with literature and various learning games. Students are offered to do project work. The frequency of the used methods depends on the topic of the intended lesson and the availability of materials. Some topics are very suitable for laboratory work and experiments, as well as for organizing interactive games on the subject. Interviews with biology teachers showed that such methods as role-playing, problem-solving tasks and debates are less commonly used, however, these methods also could be important in promoting the development of students' research skills.

The surveyed biology teachers rate the students' research skills as good. Some students have problems at different stages of the research, such as gathering information, formulating conclusions, but the teacher always tries to discuss the problem, which makes confusion and solve the problems together. Teachers pointed out that some students have low self-esteem, so they are not able to assess their knowledge and skills at the appropriate level. Teachers believe that students engage with interest in practical activities, which not only make lessons more interesting but also promote students' collaboration skills and develop students' research skills. Students prefer practical activities that are closely related to students' current problems, such as laboratory work on body balance. The answers given in the interviews show that the teachers have understood that the active participation of students in the learning process and perhaps the learning achievements are very closely related to the students' personal experience and interest in the task. Teachers are convinced that one of the most important preconditions not only for the development of research skills but also for the whole process of developing students' knowledge is the formation of interest in the relevant topic. An important role of the teacher in the development of students' research skills is the promotion of students' independent activities. The cooperation of a competent teacher, who 
can always be asked questions with the student, is one of the most important factors that promote the development of students' learning achievements and research skills.

\section{Conclusions}

- Most of the surveyed students appreciate the benefits of acquiring research skills. The majority of students agree with the statement that using methods for the development of research skills makes lessons more interesting, helps to acquire knowledge and skills that will be useful in real-life situations, develops the ability to work independently, improves learning topic and encourages interest in the subject.

- Most of the surveyed students rate their level of research skills as average. The largest number of students who have assessed their level of research skills as high is in Riga Secondary School. The majority of students usually do not have problems with research activities. Students consider that the most difficult of the stages is nomination and justification of the hypothesis.

- The majority of surveyed students consider that most of the methods used in lessons have a middle or big influence on the development of research skills. Students consider that laboratory work has the greatest impact on the development of research skills but many of them underestimate the role of role-playing on the development of research skills.

- Students evaluate the teacher's activities in the learning process and consider that different activities used in Biology lessons promote the development of research skills. As the most important activities that promote the development of research skills students consider succession planning and management of lessons, solving real-life examples and challenges, and asking questions that help students develop an understanding of the research problem.

- The surveyed biology teachers rate the students' research skills as good. Some students have problems at different stages of the research, but it is possible to develop them by promoting interest in the relevant topic. Teachers are confident that one of the most important preconditions for the development of research skills is the formation of interest in the relevant topic. The cooperation of a competent teacher with the student is one of the most important factors that promote the development of students' learning achievements and research skills.

\section{Bibliography}

1. Aizsila A. (2013). Co-operation of Latvia University of Agriculture with Schools in Research Work. In V. Dislere (Ed.), The Proceedings of the International Scientific Conference Rural Environment. Education. Personality (REEP), 6. Jelgava: LLU, 267-274. Retrieved from https://llufb.llu.lv/conference/REEP/2013/Latvia-Univ-Agricult_REEP_2013_ISSN_2255808X-267-274.pdf

2. Anspoka Z., Kazaka D. (2019). Teachers during Education Reforms: Challenges and Opportunities. In V. Dislere (Ed.), The Proceedings of the International Scientific Conference Rural Environment. Education. Personality (REEP), 12. Jelgava: Latvia University of Life Sciences and Technologies, 22-27. doi: 10.22616/REEP.2019.002

3. Brookhart S.M. (2010). Formative Assessment Strategies for Every Classroom: An ASCD Action Tool ( $2^{\text {nd }}$ ed.). Alexandria: ASCD.

4. Čakāne L. (2018). Formatīvā vērtēšana - kas tas ir? [Formative assessment - what is it?]. Retrieved from https://www.skola2030.lv/lv/jaunumi/blogs/formativa-vertesana-kas-tas-ir (in Latvian)

5. Chirikure T. (2020). Upper-secondary school students' approaches to science experiments in an examination driven curriculum context. Journal of Baltic Science Education, 19(4), 523-535. doi: $10.33225 / \mathrm{jbse} / 20.19 .523$

6. Engelmann K., Neuhaus B.J., Fischer F. (2016). Fostering scientific reasoning in educationMeta-analytic evidence from intervention studies. Educational Research and Evaluation, 22(5-6), 333-349. doi: 10.1080/13803611.2016.1240089

7. Grinnell F., Dalley S., Shepherd K., Reisch J. (2018). High School Science Fair: Student Opinions Regarding Whether Participation Should Be Required or Optional and Why. PLoS ONE, 13(8), e0202320. doi: 10.1371/journal.pone.0202320 
8. Kalniņa D. (2012). Pētnieciskās prasmes attīstība dabaszinībās [Development of research skills in natural sciences]. Rīga: Raka. (in Latvian)

9. Mantaniari R., Willison J., Hasdibuan M.H.E., Sulistyo U., Dewi F. (2020). Portraying Students' Critical Thinking Skills through Research Skill Development (RSD) Framework: A Case of a Biology Course in an Indonesian University. Journal of Turkish Science Education, 17(2), 302-314. doi: $10.36681 /$ tused.2020.28

10. McPherson H., Dubé M. (2016). Reducing the Information Literacy Gap in High School Students: An Action Research Study. Knowledge Quest, 45(2), 48-55. Retrieved from https://files.eric.ed.gov/fulltext/EJ1119276.pdf

11. Nunaki J.H., Damopolii I., Kandowangko N.Y., Nusantari E. (2019). The Effectiveness of Inquiry-Based Learning to Train the Students' Metacognitive Skills Based on Gender Differences. International Journal of Instruction, 12(2), 505-516. doi: 10.29333/iji.2019.12232a

12. Nurtamara L., Sajidan M., Suranto S., Prasetyanti N.M. (2020). The Effect of Biotechology Module with Problem Based Learning in the Socioscientific Context to Enhance Students' Socioscientific Decision Making Skills. International Education Studies, 13(1), 11-20. doi: 10.5539/ies.v13n1p11

13. Porozovs J., Dudkina A., Valdemiers A. (2019). The Use of Information and Communication Technologies of Pedagogical Specialities Students in the Study Process. In V. Dislere (Ed.), The Proceedings of the International Scientific Conference Rural Environment. Education. Personality (REEP), 12. Jelgava: Latvia University of Life Sciences and Technologies, 104-110. doi: 10.22616/REEP.2019.013

14. Regulations Regarding the State General Secondary Education Standard and Model General Secondary Education Programmes. (2019). Cabinet Regulation No. 416. Riga: Cabinet of Ministers. Retrieved from https://likumi.lv/ta/en/en/id/309597

15. Scherff L., Rush L.S. (2019). Student Research Done Right! A Teacher's Guide for High School and College Classes. McREL International.

16. Schiffl I. (2020). How Information Literate Are Junior and Senior Class Biology Students? Research in Science Education, 50(2), 773-789. doi: 10.1007/s11165-018-9710-2

17. Susetyarini E., Fauzi A. (2020). Trend of Critical Thinking Skill Researches in Biology Education Journals across Indonesia: From Research Design to Data Analysis. International Journal of Instruction, 13(1), 535-550. doi: 10.29333/iji.2020.13135a

18. Van Damme D. (2014). Inovatīvas skolas, skolotāji un mācību vide - nosacījums labākiem mācīšanās rezultātiem [Innovative schools, teachers and learning environments - a condition for better learning outcomes]. Retrieved from:

https://www.tip.edu.lv/media/files/OECD_Innovative_schools_21_08_2014.pdf (in Latvian)

19. Vronska N. (2016). ICT Competences as a Necessary Part of Professional Qualities at the Latvia University of Agriculture. In V. Dislere (Ed.), The Proceedings of the International Scientific Conference Rural Environment. Education. Personality (REEP), 9. Jelgava: LLU, 122-127. Retrieved from https://llufb.llu.lv/conference/REEP/2016/Latvia-Univ-Agricult-REEP2016proceed2255-808X-122-127.pdf

20. Zhang S. (2008). A Research Project-Based and Self-Determined Teaching System of Molecular Biology Techniques for Undergraduates. Biochemistry and Molecular Biology Education, 36(3), 181-188. doi: 10.1002/bmb.20167

21. Zhanguzhinova M.Y., Magauova A.S., Nauryzbaeva A.S. (2016). Competence Approach in Vocational Education of Kazakhstan in Conditions of Innovational and Industrial Development of the Society. In V. Dislere (Ed.), The Proceedings of the International Scientific Conference Rural Environment. Education. Personality (REEP), 9. Jelgava: LLU, 128-133. Retrieved from https://lufb.llu.lv/conference/REEP/2016/Latvia-Univ-Agricult-REEP-2016proceed2255-808X-128133.pdf 